UDC $613.2+614.31+613.636$

DOI: $10.21668 /$ health.risk/2020.2.10.eng

\title{
BACTERIAL PROFILES AND PHENOTYPIC BIOMARKERS OF MICROBIOTA ISOLATES IN HABITAT: HAZARD IDENTIFICATION FACTORS
}

\author{
N.V. Dudchik ${ }^{1}$, S.I. Sychik ${ }^{1}$, O.E. Nezhvinskaya ${ }^{1}$, N.D. Kolomiets ${ }^{2}$, E.V. Fedorenko ${ }^{1}$, \\ E.V. Drozdova ${ }^{1}$, O.V. Tonko ${ }^{2}$, O.A. Emel'yanova ${ }^{1}$ \\ ${ }^{1}$ Scientific Practical Centre of Hygiene, 8 Akademicheskaya Str., Minsk, 220012, Belarus \\ ${ }^{2}$ Belarus Medical Academy for Post-graduate Studies, 3/3 P. Brovki Str., Minsk, 220013, Belarus
}

The present work focuses on assessing bacterial profiles of microbiota existing on technological equipment applied in food products manufacturing, objects located inside medical and preventive facilities, and water objects in recreation zones; another goal was to examine phenotypic properties of opportunistic pathogenic bacteria isolates as hazard identification factors within the framework of risk assessment concept.

Our research objects were strains of Escherichia, Klebsiella, Enterobacter, Staphylococcus, Pseudomonas, Citrobacter and Serratia families that were detected and extracted due to hygienic monitoring activities performed in 2013-2017.

Samples were taken via washing, direct inoculation, membrane filtration, and instrumental aspiration technique. Microbial status was analyzed with cultural and biochemical techniques on nutrient and differential-diagnostic media with subsequent confirmation with polymerase chain reaction (PCR). Phenotypic peculiarities were examined in vitro with conventional biochemical and microbiological techniques in conformity with the requirement fixed in Good Laboratory Practice.

We revealed peculiarities of microbial profiles belonging to opportunistic pathogenic microbiota on different objects in habitats. The greatest groups included staphylococci detected in the air inside medical organizations with 1-4 cleanness degree (44\%); Enterobacteriaceae family bacteria, in washes off objects located in manufacturing and medical and prevention facilities (64\% and $69 \%$ accordingly); Pseudomonas family bacteria, in water objects (46\%). $60(36 \%)$ isolates out of 167 examined ones had modified morphological and tinctorial signs regarding those typical for a family. Most isolates had a set of modified or atypical metabolomic signs such as hemolytic and lecithinase activities, apparent persistent factors, and ability to create biofilms. Opportunistic pathogenic bacteria strains extracted from washes off objects located inside food products manufacturing and medical and preventive facilities were the most potentially aggressive. Isolates from the same families extracted from water objects in recreation zones and air inside medical and preventive facilities had less apparent phenotypic properties that characterized their pathogenic potential. Our experimental data provide useful materials for examining a phenomenon related to changes in phenotypic properties; they can be applied during revealing and drawing up a hazard profile and for minimizing uncertainty within the concept of microbiological risk analysis.

Key words: microorganisms, microbiota, microbial status, contamination, biomarkers, biofilms creation, recovery techniques, microbiologic risk analysis.

(C) Dudchik N.V., Sychik S.I., Nezhvinskaya O.E., Kolomiets N.D., Fedorenko E.V., Drozdova E.V., Tonko O.V., Emel'yanova O.A., 2020

Natal'ya V. Dudchik - Doctor of Biological Sciences, Associate Professor, Head of Microbiology Laboratory (e-mail: n_dudchik@mail.ru, n_dudchik@tut.by; tel.: +375 (17) 284-13-85; ORCID: https://orcid.org/0000-0002-5877-9307).

Sergei I. Sychik - Candidate of Medical Sciences, Associate Professor, Director (e-mail: rspch@rspch.by; tel.: +375 (17) 284-13-70; ORCID: http://orcid.org/0000-0002-5493-9799).

Ol'ga E. Nezhvinskaya - Junior researcher at the Laboratory of Microbiology (e-mail: rscph@rscph.by; tel.:+375 (17) 284-13-85; ORCID: https://orcid.org/0000-0002-4456-5922).

Natal'ya D. Kolomiets - Doctor of Medical Sciences, Professor, Head of the Department for Epidemiology and Microbiology (e-mail: ndkolomiets@mail.ru; tel.:+375 (17) 265-33-41; ORCID: http://orcid.org/0000-0002-4837-5181).

Ekaterina V. Fedorenko - Candidate of Medical Sciences, Associate Professor, doctoral candidate, Deputy Director responsible for support of practical sanitary-epidemiologic surveillance and work with the Eurasian Economic Commission (e-mail: rscph@rscph.by; tel.: +375 (17) 284-13-70; +375 (17) 284-03-45; ORCID: http://orcid.org/0000-0003-1240-1234).

Elena V. Drozdova - Candidate of Medical Sciences, Associate Professor, doctoral candidate, Deputy Director responsible for research (e-mail: rscph@rscph.by; tel.: +375 (17) 284-13-70, +375 (17) 284-03-45; ORCID: http://orcid.org/0000-0002-3032-0895).

Oksana V. Tonko - Candidate of Medical Sciences, Associate Professor at the Department for Epidemiology and Microbiology (e-mail: oxana_tonko@tut.by; tel.: +375 (17) 265-33-41; ORCID: https://orcid.org/0000-0002-5877-9307).

Ol'ga A. Emel'yanova - Candidate of Biological Sciences, Senior researcher at the Laboratory of Microbiology (e-mail: rscph@rscph.by; tel.: +375 (17) 284-13-70,+375 (17) 284-03-45; ORCID: https://orcid.org/0000-0001-6853-3431). 
Contemporary medical and biological technologies and laboratory practices provide wide opportunities to examine microorganisms' properties both at phenotypic and genotypic levels; they give an insight into ecologic, physiological, and population aspects of microbiota and it helps providing hygienic safety of the environment people live in. Use of predictive biomarkers as significant instruments in the process enables understanding and studying mechanisms for strains' pathogenic potential occurrence taking into account anthropogenic loads on microbiota created by environmental objects. Such an approach is substantiated with provisions of effective biomedical technology «omics». Over the last years scientists have been making attempts to create a basis for constructive discussions, understanding, integration and use of omics data within the concept of microbiological risk existing in food and water matrices. Integration is aimed at solving certain tasks arising in microbiological risk assessment: study on phenotypic and genotypic variability and changeability of microorganisms; multidirectional interactions with biotic and abiotic environmental factors including changes in sets of biomarkers that create pathogenic and virulent potential. It provides the most complete identification of microbiological hazards and creation of objective risk profiles; it also minimizes uncertainties in risk analysis procedures $[1,2]$.

There is a phenomenon related to opportunistic and emergent infections; it has become a separate medical and biological problem. The phenomenon can be explained via phenotypic and genotypic signs being modified, including etiologic and pathogenetic properties of opportunistic pathogenic microorganisms under exposure to quantitatively and qualitatively changing anthropogenic factors $[3,4]$. Food products, technological processes applied in food manufacturing, water objects, and environment inside medical and preventive organizations are viewed as completely new ecological niches that have occurred due to industrial development and considerable anthropogenic loads. All the above mentioned makes it necessary to perform more profound research on properties of microbiota existing in certain environmental objects, especially given wide and systematic use of modifying factors (disinfectants, preservatives, and physical factors) in order to develop efficient measures aimed at microbiological risks management.

Our research goal was to experimentally determine bacterial profiles typical for isolates of opportunistic pathogenic microbiota existing on and in certain anthropogenic environmental objects; another goal was to examine physiological, biochemical, tinctorial, and morphological biomarkers of pathogenic potential and then apply them in creating a microbiological risk profile.

Data and methods. A procedure for detecting microorganisms on surfaces of technological equipment installed at food production facilities and on objects located inside medical and preventive organizations. We applied wash-offs as the most conventional and most widely used method in field observations. Wash-offs were obtained with sterile wetted cotton tampons. A sample taken off a surface with its square being $10 \times 10 \mathrm{~cm}\left(100 \mathrm{~cm}^{2}\right)$ was considered to be representative.

A procedure for detecting microorganisms from surface water objects located in recreational zones. We applied direct inoculation and membrane filtration of water samples.

A procedure for detecting microorganisms in air inside medical and preventive facilities. Air samples with their volume being $100-500 \mathrm{dm}^{3}$ were taken via instrumental aspiration on contact Petri dishes with nutritional or differential-diagnostic media.

Microbe status of all taken samples was analyzed with cultural procedures in nutritional and differential-diagnostic media; incubation was performed under conditions optimal for a detected microorganism. We took into account all colonies that emerged on the surface and within agar layers.

Identification up to pure culture species was performed with VITEK (Biomerieux) microbiological analyzer after samples had been dyed as per Gram; verification was per- 
formed with polymerase chain reaction (PCR) according to GLP principles.

Hemolytic and lecitinase activity and ability to persist were assessed with the use of a pure daily culture after it had been cultivated on nutritional agar for 18-24 hours under optimal temperature according to the procedure described in $[5,6]$. Ability to create films was examined with an optical technique and cultivating on plates; detection was accomplished at $\chi=540 \mathrm{~nm}$ and results were interpreted as per Stepanovic criterion [6].

All the measuring and test devices applied in the research were properly verified and calibrated.

Results and discussion. We examined bacterial profiles of objects located at food productions and inside medical and preventive facilities, air inside medical and preventive facilities, and water object located in recreational zones.

We should note that it is critically important to select well-grounded procedures for detecting bacterial strains in environmental objects and examining their phenotypic properties in order to perform truly representative microbiological monitoring. Acceptability of such procedures is based on assessing a type, essence, and microbial contamination of monitoring objects [7].

Microbiota plays an important role both in maintaining ecological balance and in providing hygienic safety of environmental objects; therefore, determining profiles of bacterial community can give us some additional information about potential risks $[8,9]$.

In this research we determined bacteriological profiles and examined phenotypic properties of microbiota existing in recreational zones near three water basins located in Minsk region in spring and summer. During that period we detected and examined more than 100 bacterial isolates, most of them having properties typical for psychrophylic or mesophilic saprophyte bacteria (69\%); microbial community structure to a great extent depended on temperature regime. Our data are well in line with conclusions made in several works focusing on examining microbiome in fresh water sources $[10,11]$. S.L. Chang et al. [10] note that bacteria from Enterococcus, Staphylococcus, Streptococcus, Bacteroides, Clostridium, Finegoldia, Burkholderia, Clostridia, Bacilli and Klebsiella stems occur in water objects, and T. Gorham et al. [11] also mention rather significant contamination with Escherichiacoli indicating there is fecal contamination.

Microbial status of air and objects inside medical and preventive facilities in Minsk was examined during hygienic monitoring performed inside rooms with $1-4^{\text {th }}$ cleanness category in 2016-2018. More than 70\% out of 250 isolated strains were psychrotrophic saprophytes; mesophilic opportunistic pathogenic bacteria accounted for a smaller share as it was confirmed by several research works [12-14]. S. Lax et al. and F. Bolookat et al. [12, 13] give data on bacteria from Corynebacterium, Staphylococcus u Streptococcus stems being frequently detected in air inside medical and preventive facilities and a smaller share of detected bacteria belonging to Acinetobacter and Pseudomonas, Micrococcus and Prevotella, stems that were associated with normal microbiota existing on human skin and mucosa. S. Fujiyoshi et al. [14] also give data obtained via meta-analysis of microbiota inside medical facilities. Such stems as Corynebacterium, Streptococcus, Enterobacteriaceae, Staphylococcus, Propionibacterium, Lactococcus are also associated with normal human microbiota; Streptophyta, Pseudomonas, Acinetobacter and Sphingomonas, with air.

Microbiota existing at food production was examined at three food manufacturing facilities during hygienic monitoring performed in 2013-2015. It was reported in several works that bacterial microbiota could not only survive but also increase its population on a wide range of surfaces such as plastic, stainless steel, glass, ceramics, and wood. It can lead to cross-contamination between finished food products, food raw materials, and personnel. In some authors' opinion, dynamic control over microbial contamination is a significant tool for hygienic control over conditions existing at food production faculties and for contamination reduction [15-18]. 
Bacteria from Escherichia, Klebsiella, Enterobacter, Staphylococcus, Pseudomonas, Citrobacter and Serratia stems are widely spread microbial contaminants. They are components in microbiota existing at food productions, inside medical and preventive facilities, in water object located in recreational zones and represent a habitat of emergent and opportunistic infections that are transferred with food, water, and air. In this research we isolated, identified, and examined 167 opportunistic pathogenic microorganisms' strains. 59 isolates were isolated from surfaces of technological equipment installed at food productions; 35 isolates, from objects located inside medical and preventive faculties; 34 isolates, from air inside medical and preventive facilities; 39 isolates, from surface water objects located in recreational zones.

Apart from bacterial isolates, we detected more than 90 cases when objects were contaminated with yeast fungi from Candida stem, mold fungi from Penicillium and Aspergillu, stems; pathogenic bacteria from $\mathrm{Le}$ gionella stem were detected in one water sample; pathogenic bacteria from Salmonella and Listeria stems were not detected in wash-offs from equipment installed at food productions (these data are not given here).

Experimental data are given in Table 1.

Table 1

Phenotypic properties of bacterial isolates isolated from wash-offs taken from objects located at food productions, objects and air inside medical and preventive facilities, and water object located in recreational zones

\begin{tabular}{|c|c|c|c|c|c|c|}
\hline \multirow[b]{2}{*}{ Stem } & \multicolumn{6}{|c|}{ Phenotypic properties } \\
\hline & Hemolysis & $\begin{array}{c}\text { Anti- } \\
\text { lisozyme } \\
\text { activity }\end{array}$ & $\begin{array}{c}\text { Anti- } \\
\text { interferon } \\
\text { activity }\end{array}$ & $\begin{array}{c}\text { Lecitinase } \\
\text { activity }\end{array}$ & $\begin{array}{l}\text { Film } \\
\text { creation }\end{array}$ & $\begin{array}{c}\text { Morphologic } \\
\text { and tinctorial } \\
\text { signs }\end{array}$ \\
\hline \multicolumn{7}{|c|}{ Wash-offs from food productions } \\
\hline $\begin{array}{l}\text { Escherichia } \\
\text { (18 isolates) }\end{array}$ & $\gamma$ & $+/-$ & $+/-$ & - & $+/-$ & variable \\
\hline $\begin{array}{l}\text { Klebsiella } \\
(6 \text { isolates })\end{array}$ & $\gamma$ & $+/-$ & $+/-$ & $+/-$ & $\max$ & variable \\
\hline $\begin{array}{l}\text { Serratia } \\
(6 \text { isolates })\end{array}$ & $\gamma$ & $+/-$ & $+/-$ & - & $+/-$ & variable \\
\hline $\begin{array}{l}\text { Enterobacter } \\
(5 \text { isolates })\end{array}$ & $\gamma$ & $+/-$ & $+/-$ & - & $+/-$ & variable \\
\hline $\begin{array}{l}\text { Citrobacter } \\
(3 \text { isolates })\end{array}$ & $\gamma$ & $+/-$ & $+/-$ & $+/-$ & $+/-$ & variable \\
\hline $\begin{array}{l}\text { Staphylococcus } \\
\text { (11 isolates) }\end{array}$ & $\alpha / \beta$ & $+/-$ & $+/-$ & +- & $\min$ & variable /stable \\
\hline $\begin{array}{l}\text { Pseudomonas } \\
(10 \text { isolates })\end{array}$ & $\alpha / \beta$ & $+/-$ & $+/-$ & $+/-$ & + & variable /stable \\
\hline \multicolumn{7}{|c|}{ Wash-offs taken from objects located inside medical and preventive facilities } \\
\hline $\begin{array}{l}\text { Escherichia } \\
(9 \text { isolates }) \\
\end{array}$ & $\gamma$ & $+/-$ & $+/-$ & $+/-$ & $+/-$ & variable /stable \\
\hline $\begin{array}{l}\text { Klebsiella } \\
(4 \text { isolates })\end{array}$ & $\gamma$ & $+/-$ & $+/-$ & $+/-$ & $+/-$ & variable /stable \\
\hline $\begin{array}{l}\text { Serratia } \\
(3 \text { isolates }) \\
\end{array}$ & $\gamma$ & $+/-$ & $+/-$ & $+/-$ & $+/-$ & variable /stable \\
\hline $\begin{array}{l}\text { Enterobacter } \\
(4 \text { isolates })\end{array}$ & $\gamma$ & $+/-$ & $+/-$ & $+/-$ & $+/-$ & variable /stable \\
\hline $\begin{array}{l}\text { Citrobacter } \\
(4 \text { isolates })\end{array}$ & $\gamma$ & $+/-$ & $+/-$ & $+/-$ & $+/-$ & variable /stable \\
\hline
\end{tabular}


N.V. Dudchik, S.I. Sychik, O.E. Nezhvinskaya, N.D. Kolomiets, E.V. Fedorenko, E.V. Drozdova, O.V. Tonko ...

\begin{tabular}{|c|c|c|c|c|c|c|}
\hline $\begin{array}{l}\text { Staphylococcus } \\
(6 \text { isolates) }\end{array}$ & $\alpha / \beta$ & $+/-$ & $+/-$ & $+/-$ & $+/-$ & variable /stable \\
\hline $\begin{array}{l}\text { Pseudomonas } \\
(5 \text { isolates })\end{array}$ & $\alpha$ & $+/-$ & $+/-$ & $+/-$ & $+/-$ & variable /stable \\
\hline \multicolumn{7}{|c|}{ Air samples taken inside medical and preventive facilities } \\
\hline $\begin{array}{l}\text { Escherichia } \\
(3 \text { isolates })\end{array}$ & $\gamma$ & $+/-$ & $+/-$ & - & $+/-$ & stable \\
\hline $\begin{array}{l}\text { Klebsiella } \\
(1 \text { isolates })\end{array}$ & $\gamma$ & $+/-$ & $+/-$ & - & $+/-$ & stable \\
\hline $\begin{array}{l}\text { Serratia } \\
(1 \text { isolates })\end{array}$ & $\gamma$ & $+/-$ & $+/-$ & - & $+/-$ & variable /stable \\
\hline $\begin{array}{l}\text { Enterobacter } \\
(1 \text { isolates })\end{array}$ & $\gamma$ & $+/-$ & $+/-$ & - & $+/-$ & variable /stable \\
\hline $\begin{array}{l}\text { Citrobacter } \\
(2 \text { isolates }) \\
\end{array}$ & $\gamma$ & $+/-$ & $+/-$ & - & $+/-$ & stable \\
\hline $\begin{array}{l}\text { Staphylococcus } \\
(15 \text { isolates })\end{array}$ & $\alpha / \beta$ & $+/-$ & $+/-$ & $+/-$ & $+/-$ & variable /stable \\
\hline $\begin{array}{l}\text { Pseudomonas } \\
(12 \text { isolates })\end{array}$ & $\alpha$ & $+/-$ & $+/-$ & $+/-$ & $+/-$ & stable \\
\hline \multicolumn{7}{|c|}{ Water samples taken from water object in recreational zones } \\
\hline $\begin{array}{l}\text { Escherichia } \\
(6 \text { isolates })\end{array}$ & $\gamma$ & $+/-$ & $+/-$ & - & $+/-$ & variable /stable \\
\hline $\begin{array}{l}\text { Klebsiella } \\
(2 \text { isolates }) \\
\end{array}$ & $\gamma$ & $+/-$ & $+/-$ & - & $+/-$ & variable /stable \\
\hline $\begin{array}{l}\text { Serratia } \\
(1 \text { isolate })\end{array}$ & $\gamma$ & $+/-$ & $+/-$ & - & $+/-$ & variable /stable \\
\hline $\begin{array}{l}\text { Enterobacter } \\
(2 \text { isolates })\end{array}$ & $\gamma$ & $+/-$ & $+/-$ & - & $+/-$ & variable /stable \\
\hline $\begin{array}{l}\text { Citrobacter } \\
(2 \text { isolates }) \\
\end{array}$ & $\gamma$ & $+/-$ & $+/-$ & - & $+/-$ & variable /stable \\
\hline $\begin{array}{l}\text { Staphylococcus } \\
(8 \text { isolates })\end{array}$ & $\alpha / \beta$ & $+/-$ & $+/-$ & $+/-$ & $+/-$ & variable /stable \\
\hline $\begin{array}{l}\text { Pseudomonas } \\
(18 \text { isolates })\end{array}$ & $\alpha$ & $+/-$ & $+/-$ & $+/-$ & $\max$ & variable /stable \\
\hline
\end{tabular}

Bacteria from Enterobacteriaceae family most frequently occurred in wash-offs from objects located at food productions and inside medical and preventive facilities, accounting for $64 \%$ and $69 \%$ of the total opportunistic pathogenic bacteria accordingly. Their share was $24 \%$ in air inside medical and treatment facilities and $33 \%$ in water objects. Staphylococci prevailed among opportunistic pathogenic microorganisms occurring in air inside medical and preventive facilities (44\%). Bacteria from Pseudomonas stem took the leading place among pathogens in water objects (46\%).

In our research 60 opportunistic pathogenic isolates out of 167 examined ones $(36 \%)$ had obvious morphologic and tinctorial signs that were modified in comparison to those typical for a specific stem; these modifications included tint variability as per Gram, intrapopulation cells polymorphism that became apparent through sizes, shapes of cells and colonies, etc.

It was noted in several research works that virulence and pathogenicity of microbial contaminants were enhanced by exogenous secretion of certain enzymes and toxins produced by bacteria [19-21]. We revealed in our work that opportunistic pathogenic bacteria isolates detected on objects located at food productions and inside medical and preventive facilities and in water objects located in recreational zones had atypical or modified prop- 
erties such as hemolytic and lecitinase activity, greater ability to persist, and ability to create biofilms.

$\beta$-hemolytic activity was revealed in all the examined $S$. aureus isolates; several Staphylococcus spp isolates with incomplete hemolytic activity was detected in air; $\alpha$-hemolytic activity was revealed in $P$. aeruginosa isolates detected in water objects and wash-off from technological equipment; certain Pseudomonas stem isolates turned out to be able to accomplish complete hemolysis, even under increased temperature, and it can indicate that they were able to produce two types of hemolysins, thermolabile phospholipase $\mathrm{C}$ and thermostable glycolipid. Isolates from Enterobacteriaceae family had $\gamma$-hemolytic activity.

100\% examined Staphylococcus aureus strains had lecitinase activity. Anti-interferon and anti-lysozyme activities as persistence factors are aimed at inactivating protection mechanisms a host might have. These phenotypic properties were the most apparent in isolates from Staphylococcus stem, and a type of object those isolates were detected in didn't make any significant difference regarding persistence properties intensity. 15 out of 39 Staphylococcus isolates had anti-lysozyme activity under lysozyme concentration being $4 \mathrm{mg} / \mathrm{ml}$ or lower; 23 strains had anti-interferon activity under interferon concentration being $2 \mathrm{IU} / \mathrm{ml}$, and other strains, under concentration being $1 \mathrm{IU} / \mathrm{ml}$. This phenomenon correlates well with Staphylococci strains growing quite intensely in nutritional agar with fucidin under fucidin concentration being equal to $0.00015-0.0003 \mathrm{mg} / \mathrm{ml}$.

Bacteria from Pseudomonas stem produced pigments from pyocyanin and pyoverdine groups while pigments from pyomelanin group were produced by a few isolates only, and pigment formation occurred with significantly different intensity. We isolated five strains that produced two pigments simultaneously; most isolates produced pigments from one group; and we also detected an isolate without any pigments. At present mutations that result in weaker ability to produce pig- ments are viewed by researchers as mechanisms that enhance pathogenic potential this bacterium has, in particular in case of polymicrobe infection.

However, it is films creation that is the most perfect and complicated strategy adopted by bacteria as a response to impacts exerted by environmental factors. Examined strains had different abilities to create biofilms in a monoculture. All Klebsiella pneumonia strains were greatly able to create films according to Stepanovic criterion. Coagulase-negative staphylococci (S. haemoliticus, S. sciuri, S.epidermidis) had minimal activity regarding films creation. Coagulase-positive staphylococci were more active as regards biofilms creation in a model experiment and it is also confirmed by recent research data on hemolysin participation in creating $S$. aureus biofilm [21]. An ability by bacteria to create biofilms is interesting due to the fact that many microorganisms can change their properties, and their consortium - in a form of a biofilms - can acquire new properties that are not characteristic for strains that are included into it. According to some authors, inter-species communications among bacteria can make for synchronization of specialized functions performed by different species in a group. Phenotypic properties of strains in a biofilms differ considerably from properties that are typical for a microorganism stem and species. It has to do with metabolic activity parameters; ability to produce exogenous enzymes; persistence or sensitivity to antibiotics, sulfonamides, disinfectants; resistance to impacts exerted by adverse physical environmental factors (temperature, $\mathrm{pH}$, osmotic concentration, and irradiation); existing epidemically significant markers etc.

Use of «omics» principles is an up-to-date and quite efficient approach to further methodological development of microbiological risks assessment; these principles, among other things, should be aimed at examining phenotypic variability in order to minimize uncertainties in risk analysis procedures. Authors that describe this approach are sure that «omics» technologies provide correct use of biomarkers as tools for understanding signifi- 
cance of dynamic changes in microorganisms' phenotypic parameters for strain pathogenesis. Certain pathogens exist as quasi-stems that are fluctuating populations made of genetically heterogeneous variants existing within one object $[1,2]$.

A population, a community, and an ecosystem are dynamic levels that characterize microbiota existing in different environmental objects. Microbial pathogens perform a lot of interactions with representatives from their species, other species, and abiotic environment. Thus, microbiota representatives compete for resources and it results in pathogenic factors and virulence becoming more intense in opportunistic pathogenic microorganisms thus making ecologic dynamics of their prevalence and distribution much more complicated.

Isolates of opportunistic pathogenic microorganisms with modified phenotypic properties that are isolated from environmental objects can be efficient test-models for revealing and quantitative assessment of anti-microbial impacts and hygienic regulation of chemical, physical, or biological environmental factors. It happens so due to them being highly specific and sensitive in a model experiment. We detected certain dependence between microorganisms' sensitivity to adverse chemical exposure and their ability to create films. In our opinion, further research in the sphere can focus on assessing biological impacts exerted by environmental factors with complex chemical, physical, and biological nature [22].

\section{Summary.}

1. Microbial profile of opportunistic pathogenic microbiota is different for different environmental objects. Thus, the leading roles belong to staphylococci in air inside medical and preventive organizations (44\%); to bacteria from Enterobacteriaceae family, in wash-offs from technological equipment and objects inside medical and preventive organizations $(64 \%$ and $69 \%$ of the total opportunistic pathogenic bacteria accordingly); to bacteria from Pseudomonas stem, in water objects $(46 \%)$.

2. In our research 60 opportunistic pathogenic bacteria isolates out of examined
$167(36 \%)$ had obvious morphologic and tinctorial signs that were modified in comparison to those typical for a specific stem including tint variability as per Gram, cells polymorphism etc. Most isolates from object inside medical and preventive facilities, food productions, and water objects located in recreational zones had a set of modified properties regarding their pathogenicity potential such as hemolytic and lecitinase activity, apparent persistence factors, and ability to create biofilms. Differences in pathogenicity potential of opportunistic pathogenic microorganisms isolated from different environmental objects can be due to quantitative parameters of biomarkers that create this potential depending on multiple complicated interactions between anthropogenic selection factors in the environment.

3. Our analysis revealed that opportunistic pathogenic bacteria strains isolated from wash-offs from objects located at food productions and inside medical and preventive facilities were the most aggressive. Isolates of the same stems detected in water objects located in recreational zones and air inside medical and preventive facilities had less apparent phenotypic properties that characterized pathogenicity potential.

Conclusion. Several works contain data on such a phenomenon as microorganisms modifying their phenotypic properties under exposure to anthropogenic environmental factors; however, previously there has been no comparison between signs of opportunistic pathogenic bacteria isolates detected in different environmental objects. Experimental data in our work provide necessary material for examining and analyzing this phenomenon and it should be taken into account when detecting hazards, creating their profiles, and minimizing uncertainties within microbiological risk analysis procedures. We revealed peculiarities in microbial profiles and phenotypic properties of opportunistic pathogenic microbiota existing on and in different environmental objects. It was shown that 60 isolates ( $36 \%$ ) out of examined 167 had modified hemolytic and lecitinase activity, apparent persistent factors, and 
ability to create biofilms. Microbiota existing in and on examined objects had different structures: staphylococci accounted for the greatest share $(44 \%)$ in air inside medical and preventive facilities; bacteria from Enterobacteriaceae family, in wash-offs from equipment installed at food productions and objects located inside medical and preventive facilities (64\% and $69 \%$ accordingly); bacteria from Pseudomonas stem, in water objects (46\%). Opportunistic pathogenic bacteria strains detected in wash-offs from equipment installed at food productions and objects located inside medical and preventive facilities were potentially the most aggressive. Further research on the phenomenon related to modification of microbiota phenotypic properties in the environ- ment can enrich an existing list of opportunistic and emergent pathogenic bacteria, give scientific grounds for developing the most efficient measures aimed at managing microbiological risks associated with different environmental factors. Besides, microorganisms' strains with apparent aggressive potential are quire efficient and relevant test-models for detecting and quantitative assessment of antimicrobial impacts via creating aggravated conditions of significant microbial load in a model experiment.

Funding. The research was not granted any sponsor support.

Conflict of interests. The authors declare there is no any conflict of interests.

\section{References}

1. Den Besten H.M.W., Amézquita A., Bover-Cid S., Dagnas S., Ellouze M., Guillou S., Nychas G., O'Mahony C. [et al.]. Next generation of microbiological risk assessment: Potential of omics data for exposure assessment. Int. J. of Food Microbiol, 2018, vol. 20, no. 287, pp. 18-27. DOI: 10.1016/j.ijfoodmicro.2017.10.006

2. Haddad N., Johnson N., Kathariou S., Métris A., Phister T., Pielaat A., Tassou C. [et al.]. Next generation of microbiological risk assessment: Potential of omics data for hazard characterization. Int. J. of Food Microbiol, 2018, vol. 20, no. 287, pp. 28-39. DOI: 10.1016/j.ijfoodmicro.2018.04.015

3. Vouga M., Greub G. Emerging bacterial pathogens: the past and beyond. Clin. Microbiol. Infect, 2016, vol. 22, no. 1, pp. 12-21. DOI: 10.1016/j.cmi.2015.10.010

4. Fournier P.E., Drancourt M., Raoult D. New laboratory tools for emerging bacterial challenges. Clin. Infect. Dis., 2017, vol. 15, no. 65 (1), pp. S39-S49. DOI: 10.1093/cid/cix405

5. Metody obshchei bakteriologii [General bacteriology techniques]. In: F. Gerkhardt [et al.] eds. Moscow, Mir Publ., 1984, vol. 3, 536 p. (in Russian).

6. Nezhvinskaya O.E., Dudchik N.V., Kolomiets N.D., Tonko O.V., Drozdova E.V. Metody otsenki epidemiologicheskoi znachimosti uslovnopatogennoi mikroflory [Techniques for assessing epidemiologic significance of opportunistic pathogenic microflora]. Zdorov'e $i$ okruzhayushchaya sreda: sbornik nauchnykh trudov. In: S.I. Sychik ed. Minsk, RNMB Publ., 2015, vol. 1, no. 25, pp. 69-71 (in Russian).

7. Ismail R., Aviat F., Michel V., Le Bayon I., Gay-Perret P., Kutnik M., Fédérighi M. Methods for recovering microorganisms from solid surfaces used in the food industry: a review of the literature. Int. $J$. Environ. Res. Public Health, 2013, vol. 10, no. 11, pp. 6169-6183. DOI: 10.3390/ijerph10116169

8. Weikl F., Tischer C., Probst A.J., Heinrich J., Markevych I., Jochner S., Pritsch K. Fungal and Bacterial Communities in Indoor Dust Follow Different Environmental Determinants. PLoS One, 2016, vol. 21, no. 11 (4), pp. e0154131. DOI: 10.1371/journal.pone.0154131

9. Wang L., Zhang J., Li H., Yang H., Peng C., Peng Z., Lu L. Shift in the microbial community composition of surface water and sediment along an urban river. Science of The Total Environ, 2018, vol. 15 , no. 627 , pp. 600-612. DOI: 10.1016/j.scitotenv.2018.01.203

10. Lee C.S., Kim M., Lee C., Yu Z., Lee J. The microbiota of recreational freshwaters and the implications for environmental and public health. Front. Microbiol, 2016, vol. 7, pp. 1826. DOI: $10.3389 /$ fmicb.2016.01826

11. Gorham T., Lee J. Pathogen loading from Canada geese faeces in freshwater: potential risks to human health through recreational water exposure. Zoonoses Public Health, 2016, vol. 63, no. 3, pp. 177-190. DOI: 10.1111/zph.12227 
12. Lax S., Smith D., Sangwan N., Handley K., Larsen P., Richardson M., Taylor S., Landon E. [et al.]. Colonization and succession of hospital-associated microbiota. Sci. Transl. Med, 2017, vol. 9, no. 391, pp. eaah6500. DOI: 10.1126/scitranslmed.aah6500

13. Bolookat F., Hassanvand M.S., Faridi S., Hadei M., Rahmatinia M., Alimohammadi M. Assessment of bioaerosol particle characteristics at different hospital wards and operating theaters: A case study in Tehran. Methods X, 2018, vol. 5, pp. 1588-1596. DOI: 10.1016/j.mex.2018.11.021

14. Fujiyoshi S., Tanaka D., Maruyama F. Transmission of airborne bacteria across built environments and its measurement standards: a review. Front. Microbiol, 2017, vol. 8, pp. 2336. DOI: 10.3389/fmicb.2017.02336

15. Den Reijer P.M., Haisma E.M., Lemmens-den Toom N.A., Willemse J., Koning R.I., Demmers J.A., Dekkers D.H., Rijkers E. [et al.]. Detection of alpha-toxin and other virulence factors in biofilms of Staphylococcus aureus on polystyrene and a human epidermal model. PLoS ONE, 2016, vol. 11, pp. e0145722. DOI: 10.1371/journal.pone.0145722

16. Zhang H., Zheng Y., Gao H., Xu P., Wang M., Li A., Miao M., Xie X. [et al.]. Identification and characterization of Staphylococcus aureus strains with an incomplete hemolytic phenotype. Front. Cell Infect. Microbiol, 2016, vol. 6, pp. 146. DOI: 10.3389/fcimb.2016.00146

17. Bokulich N.A., Lewis Z.T., Boundy-Mills K., Mills D.A. A new perspective on microbial landscapes within food production. Curr. Opin. Biotechnol, 2016, vol. 37, pp. 182-189. DOI: 10.1016/j.copbio.2015.12.008

18. Wang X., Du H., Zhang Y., Xu Y. Environmental microbiota drives microbial succession and metabolic profiles during chinese liquor fermentation. Appl. Environ. Microbiol, 2018, vol. 84, no. 4, pp. e02369-e02417. DOI: 10.1128/AEM.02369-17

19. Kartashova O.L., Utkina T.M. Regulyatsiya persistentnykh svoistv mikroorganizmov faktorami razlichnoi prirody (obzor) [Persistent properties of microorganisms: regulation by different factors (review)]. Byulleten' Orenburgskogo nauch. tsentra UrO RAN, 2013, pp. 1-11 (in Russian).

20. Brauner A., Fridman O., Gefen O., Balaban N.Q. Distinguishing between resistance, tolerance and persistence to antibiotic treatment. Nat. Rev. Microbiol, 2016, vol. 14, pp. 320-330.

21. Ximenes E., Hoagland L., Ku S., Li X., Ladisch M. Human pathogens in plant biofilms: formation, physiology, and detection. Biotechnol. Bioeng, 2017, vol. 114, no. 7, pp. 1403-1418. DOI: 10.1002/bit.26247

22. Dudchik N.V. Investigation of the properties of the soil microbial consortium as a test objects for estimation of integral toxicity. Gigiena i sanitariya, 2012, vol. 91, no. 5, pp. 82-84 (in Russian).

Dudchik N.V., Sychik S.I., Nezhvinskaya O.E., Kolomiets N.D., Fedorenko E.V., Drozdova E.V., Tonko O.V., Emel'yanova O.A. Bacterial profiles and phenotypic biomarkers of microbiota isolates in habitat: hazard identification factors. Health Risk Analysis, 2020, no. 2, pp.92-100. DOI: 10.21668/health.risk/2020.2.10.eng

Received: 17.05.2019

Accepted: 03.06.2020

Published: 30.06 .2020 